\title{
FERMENTASI BATANG PISANG SEPATU (Musa Paradisiaca Forma Typica) TERHADAP PALATABILITAS SAPI BALI (Bos Sondaicus)
}

\author{
Fermentation of Banana Stem (Musa Paradisiaca Forma Typica) Silage \\ of Bali cow (Bos Sondaicus) Palatability \\ Rahmat Anwar, Nibras K. Laya*), dan Umbang A. Rokhayati \\ Jurusan Peternakan, Fakultas Pertanian, Universitas Negeri Gorontalo \\ Email:rahmatanwar291@gmail.com \\ ${ }^{*}$ Coresponding Author: nibraslaya@ung.ac.id
}

\begin{abstract}
The purpose of this study was to determine the Palatability of Bali cattle to feed banana stem silage. The study was conducted in March-April 2019 in Dambalo Village, North Gorontalo District, Indonesia. This study used 20 cattle and divided them into two groups. The first group was control, (P0 = $15 \mathrm{~kg}$ of elephant grass $+1 \mathrm{~kg}$ of fresh banana stems / head / day). The second group ( $\mathrm{P0}=15 \mathrm{~kg}$ of elephant grass $+1 \mathrm{~kg}$ of banana stems/tail/silage day) Data analysis using T-Test. The results showed that the Banana Bar Silage feed was significantly different $(\mathrm{P}>0.05)$ from the delicacy of Bali cattle., while the value of body weight gain is higher in cattle given banana stem silage compared to those given in the fresh form. The silage of banana stems fed by cattle is better than cows given in the fresh form, with a weight gain of $42-57 \mathrm{~g} /$ day.
\end{abstract}

Keywords: Bali Cattle, Fermentation, Palatability

\section{ABSTRAK}

Tujuan dari penelitian ini adalah untuk mengetahui palatabilitas sapi bali terhadap pakan batang pisang sepatu yang diferemtasi. Penelitian dilakukan pada bulan Maret-April 2019 di Desa Dambalo, Kabupaten Gorontalo Utara, Indonesia. Penelitian ini menggunakan 20 ekor sapi dan dibagi menjadi dua kelompok. Kelompok pertama adalah kontrol, ( $\mathrm{P} 0=15 \mathrm{~kg}$ rumput gajah $+1 \mathrm{~kg}$ batang pisang segar / ekor / hari). Kelompok II ( $\mathrm{P0}=15 \mathrm{~kg}$ rumput gajah $+1 \mathrm{~kg}$ batang pisang / ekor / silase hari) Analisis data menggunakan Uji-T. Hasil penelitian menunjukkan bahwa pakan Silase Batang Pisang berbeda nyata ( $\mathrm{P}>$ 0,05) dengan kelezatan sapi Bali, sedangkan nilai pertambahan bobot badan lebih tinggi pada sapi yang diberi silase batang pisang dibandingkan dengan yang diberikan dalam bentuk segar. Silase batang pisang yang diberi pakan ternak lebih baik dari pada sapi yang diberikan dalam bentuk segar, dengan pertambahan bobot badan 42-57 gr / hari.

Kata kunci:, Fermentasi, Palatabilitas, Sapi Bali

Cara Mengutip (APA Citation Style)

Anwar R, Laya N,K. dan Rokhayati U.A. 2020. Fermentasi Batang Pisang Sepatu (Musa Paradisiaca Forma Typica) Terhadap Palatabilitas Sapi Bali (Bos Sondaicus). Jambura Journal of Animal science 3(1), 8-15

(C) 2020 - Anwar R, Laya N,K. dan Rokhayati U.A. Under the license CC BY-SA 4.0 


\section{PENDAHULUAN}

Sapi bali adalah sapi potong asli Indonesia, hasil domestikasi dari Banteng (Bos-bibosbanteng) (Hardjosubroto, 1994), sapi ini berasal dari pulau bali, mempunyai kemampuan reproduksi tinggi, dapat digunakan sebagai ternak kerja di sawah dan ladang (Putu dkk., 1998; Moran, 1990), persentase karkas tinggi, daging tanpa lemak, heterosis positif tinggi pada persilangan (Pane, 1990), serta daya adaptasi yang tinggi terhadap lingkungan, dengan persentase kelahiran mencapai 80 $\%$.

Keberhasilan usaha pemeliharaan ternak ditentukan oleh pakan yang diberikan. Kenyataan dilapangan menunjukan bahwa masih banyak peternak yang memberikan pakan pada ternak tanpa memperhatikan kualitas, kuantitas dan cara pemberian ransum tersebut. Akibatnya pertumbuhan ataupun produktifitas ternak yang dipelihara tidak maksimal. Bahkan banyak peternak yang mengalami kerugian akibat pemberian pakan yang kurang sempurna. Keterbatasan pakan hijauan disaat kemarau juga dapat berdampak terhadap produktifitas ternak sapi, selain memanfaatkan jerami jagung sedagai pakan (Suprayogi, A., \& Mukhtar, M. 2020), dapat juga memanfaatkan batang pisang yang telah di panen (Rokhayati, U. A. dan Pateda S. Y, 2016). Penggunaan limbah batang pisang belum banyak diketahui oleh masyarakat, terutama bagi peternak pemula dalam memelihara ternak sapi

Pentingnya batang pisang untuk ternak salah satunya disebabkan batang pisang banyak mengandung karbohidrat, oleh karena gedebok pisang mempunyai kandungan karbohidrat yang bisa dimanfaatkan oleh ternak sebagai sumber pakan. Uji palatabilitas ternak sapi Bali betina dengan menggunakan pakan fermentasi dari batang pisang sepatu atau kepok (Musa paradisiaca forma typica), dengan tujuan untuk mengetahui sejauh mana daya suka ternak sapi potong terhadap pakan batang pisang sepatu di fermentasi.

\section{METODE PENELITIAN}

Penelitan ini telah dilaksanakan di bulan Maret-Juni 2019. Lokasi penelitian di Desa Dambalo Kecamatan Tomilito Kabupaten Gorontalo Utara. Ternak yang digunakan dalam penelitian ini sapi bali berjenis kelamin betina. Jumlah ternak yang digunakan dalam penelitian ini berjumlah 20 ekor. Ternak dikelompokkan menjadi dua kelompok, Kelompok pertama berjumlah 10 ekor digunakan sebagai control, dan diberikan pakan tambahan berupa batang pisang tanpa fermentasi. Kelompok ke dua berjumlah 10 ekor diberikan pakan tambahan fermentasi batang pisang. Pemberian pakan berdasarkan kebutuhan bahan kering 2.5\%.

Analisis data mengunakan uji $\mathrm{T}$ (Hanafiah, dkk. 2004). Formula uji T yang digunakan adalah:

$$
t=\frac{\overline{\mathrm{x}_{1}}-\overline{\mathrm{x}_{2}}}{\sqrt{\frac{S_{1}^{2}}{n_{1}}+\frac{S_{2}^{2}}{n_{2}}-2 r\left(\frac{S_{1}}{\sqrt{n_{1}}}\right)\left(\frac{S_{2}}{\sqrt{n_{2}}}\right)}}
$$

$\mathrm{S}_{1}^{2}=$ Keragaman Sampel 1

$\mathrm{S}_{2}^{2}=$ Keragaman Sampel 2

$\mathrm{r}=$ hubungan dua sampel

Keterangan

$\overline{\mathrm{x}_{1}}=$ Rataan perlakuan 1

$\overline{\mathrm{x}_{1}}=$ Rataan Perlakuan 2

$S_{1}=$ Simpangan baku sampel 1

$S_{2}=$ Simpangan baku sampel 2

\section{HASIL DAN PEMBAHASAN}

\section{Silase Batang Pisang}

Dua jenis pakan perlakuan yang diberikan pada sapi Bali dalam penelitian ini yaitu batang pisang segar dan batang pisang fermentasi atau silase. Terdapat perbedaan jenis kandungan nutrisi batang pisang pada jenis pisang yang berbeda ,dapat kita lihat pada tabel 1 berikut. 
Tabel 1. Perbedaan nutrisi batang pisang pada 3 jenis pisang

\begin{tabular}{lccccccccc}
\hline \multicolumn{1}{c}{ Bahan Pakan } & $\begin{array}{c}\text { BK } \\
\mathbf{( \% )}\end{array}$ & $\begin{array}{c}\text { Abu } \\
\mathbf{( \% )}\end{array}$ & $\begin{array}{c}\text { PK } \\
\mathbf{( \% )}\end{array}$ & $\begin{array}{c}\text { SK } \\
\mathbf{( \% )}\end{array}$ & $\begin{array}{c}\text { LK } \\
\mathbf{( \% )}\end{array}$ & $\begin{array}{c}\text { BETN } \\
\mathbf{( \% )}\end{array}$ & $\begin{array}{c}\text { Ca } \\
\mathbf{( \% )}\end{array}$ & $\begin{array}{c}\mathbf{P} \\
\mathbf{( \% )}\end{array}$ & $\begin{array}{c}\text { TDN } \\
(\mathbf{\%})\end{array}$ \\
\hline Batang Pisang Sepatu & 87,7 & 25,12 & 3,01 & 29,40 & 14,23 & 28,24 & - & - & - \\
Batang Pisang Ambon & 80,0 & 19,50 & 1,01 & 19,50 & 0,75 & 59,24 & - & - & - \\
Batang Pisang Raja & 82,0 & 22,03 & 2,00 & 23,14 & 5,00 & 22,35 & - & - & - \\
\hline
\end{tabular}

Sumber: Hasil olahan data 2019

Tabel 2. Perbedaan pakan yang diberikan pada perlakuan

\begin{tabular}{lll}
\hline Sifat fisik/kimiawi bahan pakan & \multicolumn{1}{c}{$\begin{array}{c}\text { Batang pisang } \\
\text { fermentasi }\end{array}$} & Batang pisang tanpa fermentasi \\
\hline Bau & Bau harum keasaman & Tidak berbau \\
Warna & Coklat muda kehijauan & Putih kehijauan \\
Jamur & Tidak terdapat jamur & Tidak terdapat jamur \\
Tekstur & Utuh dan halus & Empuk \\
\hline
\end{tabular}

Sumber: Hasil Olahan data 2019.

Berdasarkan hasil di tabel 1 diatas Kandungan batang pisang sepatu memiliki kandungan nutrisi terutama bahan kering lebih tinggi dibanding pisang Raja, pisang Ambon dan dapat di jadikan silase.

Silase batang pisang adalah salah satu produk olahan pakan ternak yang bersumber dari limbah pertanian yaitu berupa batang pisang yang ditambahkan molasses sebagai starter serta beberapa bahan lainnya dan dilakukan fermentasi selama tiga hari. Tujuan pembuatan silase adalah untuk mengawetkan bahan pakan dan memaksimalkan nutrisi dalam bahan pakan tersebut. Hal ini sesuai dengan pernyataan Balitbangtan (2015) bahwa keberhasilan pembuatan silase berarti memaksimalkan nutrien yang dapat diawetkan. Kedua jenis pakan tersebut memiliki perbedaan baik secara fisik maupun kimiawi, seperti yang tersaji pada Tabel 2.

Berdasarkan Tabel 2, terlihat bahwa silase yang dihasilkan memiliki kualitas baik. Hasil ini sejalan gan yang diungkapkan Haustein (2003) menyatakan bahwa kualitas silase yang berkualitas baik adalah berwarna hijau kecoklatan atau coklat muda, beraroma asam, bertekstur halus dan utuh.
Secara umum silase yang dihasilkan dalam penelitian ini berwarna coklat kehijauan, tidak ditemui silase yang berwarna coklat gelap atau hitam, karena semakin gelap silase yang dihasilkan maka kualitas silase semakin rendah (Despal dkk., 2011).

Perubahan warna yang terjadi selama proses fermentasi disebabkan oleh perubahan-perubahan yang terjadi pada tanaman karena proses respirasi aerobik yang berlangsung selama persediaan oksigen masih ada (Reksohadiprodjo, 1988). Gula akan teroksidasi menjadi $\mathrm{CO}_{2}$, air dan panas sehingga temperatur naik.Apabila temperatur tidak terkendali, silase akan berwarna coklat tua sampai hitam. Hal ini menyebabkan turunnya nilai pakan karena banyak sumber karbohidrat yang hilang dan kecernaan protein turun.

Silase yang dihasilkan dalam penelitian ini berbau harum keasaman, tetapi segar dan enak. Bau asam disebabkan karena bakteri anaerob (bakteri asam laktat) aktif bekerja menghasilkan asam organik (Siregar, 1996). Sedangkan tektur yang dihasilkan yaitu padat dan halus. Ditambahkan pula bahwa ciri-ciri tekstur silase yang baik adalah masih utuh seperti awal pembuatan. Tekstur silase biasanya menjadi lembek, jika kadar air hijauan atau bahan yang digunakan pada pembuatan 
silase masih cukup tinggi, sehingga silase banyak menghasilkan air. Sebelum pembuatan silase, batang pisang harus dilayukan terlebih dahulu untuk menurunkan kadar airnya. Silase batang pisang melalui proses diinokulasi dengan indigenous microorganisms

(IMO) menghasilkan tekstur halus sedikit basah, warna kuning kecoklatan, aroma asam tidak menyengat (Michael et al. 2016), sedangkan fermentasi mikroba pada jerami akan menurunkan selulosa, hemi selulosa dan lignin ( Pasue, 2019).

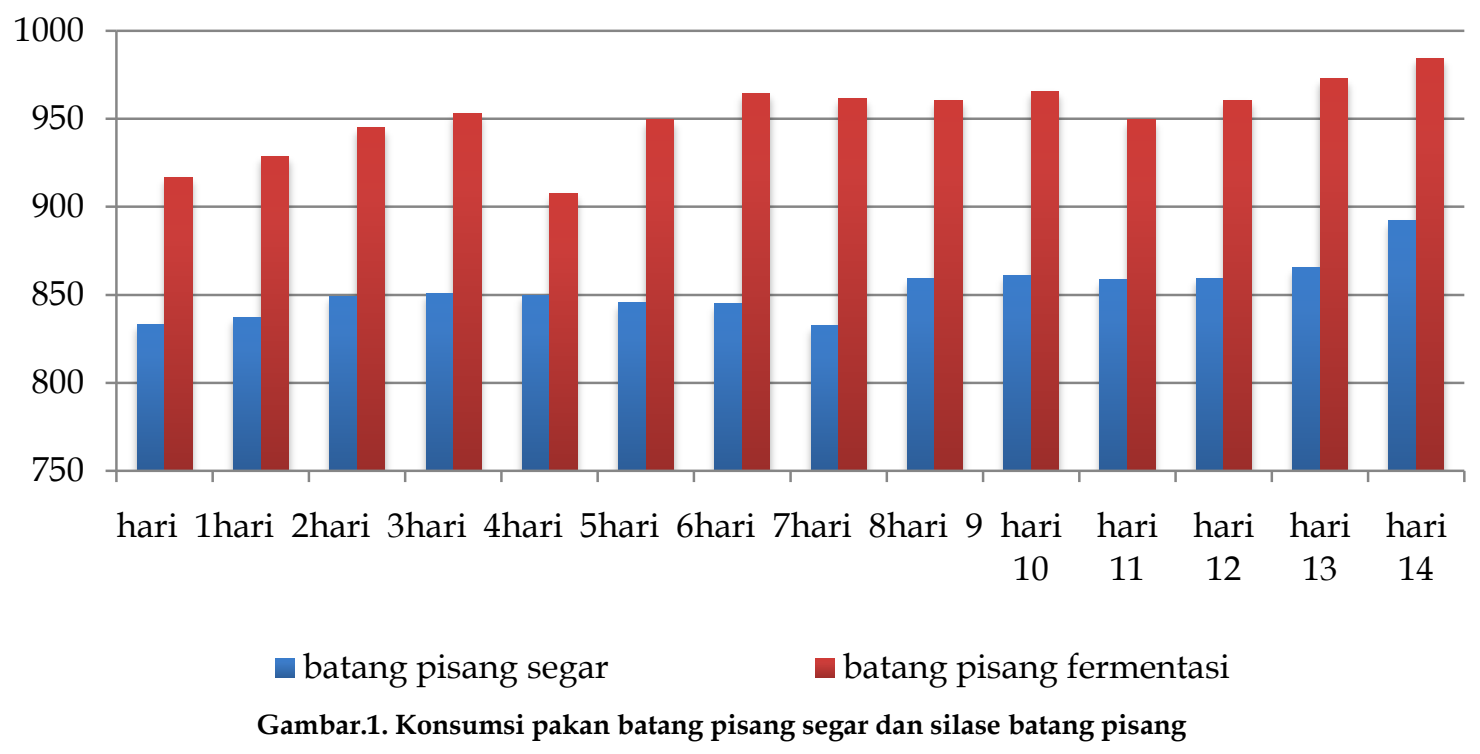

\section{Palatabilitas Sapi Bali}

Palatabilitas didefinisikan sebagai respon yang diberikan oleh ternak terhadap pakan yang diberikan dan hal ini tidak hanya dilakukan oleh ternak ruminansia tetapi juga dilakukan oleh hewan mamalia lainnya terutama dalam memilih pakan yang diberikan (Chruch dan Pond, 1988). Palatabilitas merupakan hasil keseluruhan dari faktor-faktor yang menentukan apakah dan sampai dimana suatu pakan menarik bagi ternak.Faktor-faktor tersebut adalah bau, rasa, bentuk dan temperatur pakan (Lawrence, 1990).

Berikut adalah rata-rata konsumsi pakan sapi Bali hasil penelitian antara batang pisang segar dan silase batang pisang yang tersaji pada Diagram 1 di bawah ini.. Hasil uji t menunjukkan bahwa, silase batang pisang sepatu berpengaruh nyata $(\mathrm{P}>0,05)$ atau lebih disukai oleh Hal ini dipengaruhi oleh tekstur dan bau khas yang dihasilkan sehingga disukai ternak sapi Bali dibandingkan dengan pakan batang pisang sepatu segar

Hal ini sesuai dengan pernyataan Rizkiyah dan Agustina (2016) menyatakan bentuk fisik pakan tersebut, pakan yang dicacah halus dapat menaikkan tingkat konsumsi, mempercepat pengunyahan dimana dilaporkan bahwa panjang cacahan yang lebih pendekmemungkinkan terjadinya pemadatan padasaat pembuatan silase, sehingga terjadi proses fermentasi yang lebih sempurna oleh mikroorganisme. Pada umumnya tingkat kecernaan silase yang dicacah lebih tinggi dari pada yang tidak dicacah. Ini sesuai dengan pendapat Church dan Pond (1988), menyatakan bahwa palatabilitas yang meliputi tekstur, bau, rasa, dan suhu dari pakan yang diberikan, mempengaruhi tingkat konsumsi. 


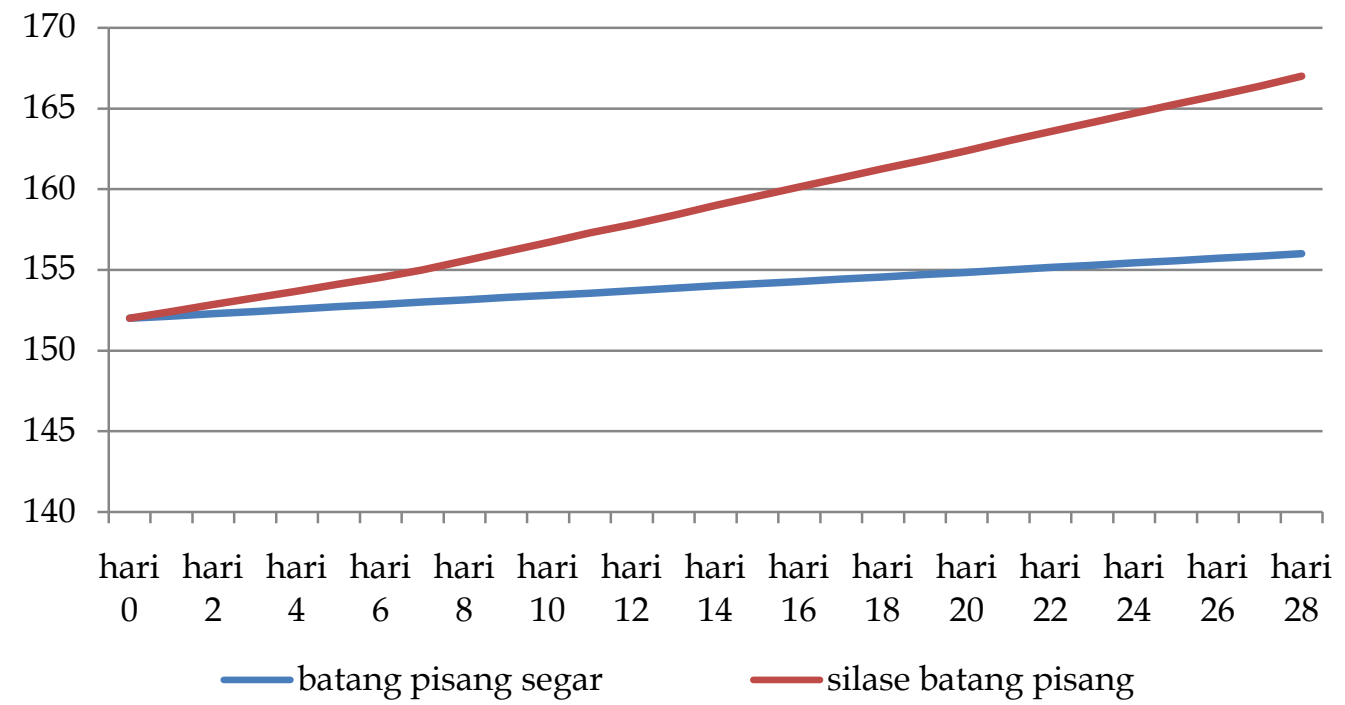

Gambar 2. Pertambahan bobot badan harian/ekor sapi Bali hasil penelitian

Menurut Wiratama (2010) menyatakan bahwa molases banyak mengandung karbohidrat sebagai sumber energi dan mineral, baik mineral makro maupun mikro, sehingga dapat memacu pertumbuhan mikroba di dalam rumen yang mengakibatkan ternak lebih mampu mencerna serat kasar. Dipenelitian ini molases dapat memperbaiki formula menjadi lebih kompak, mengandung energi yang cukup tinggi, dapat meningkatkan palatabilitas dan citarasa serta meningkatkan aktivitas mikrobia di dalam rumen. Sehingga ternak sapi Bali dalam penelitian yang memiliki tingkat palatabilitas tinggi adalah yang diberikan pakan silase batang pisang

\section{Pertambahan Bobot Badan}

Pertambahan bobot badan harian ternak sapi Bali diperoleh dari hasil penimbangan bobot badan akhir dikurangi dengan bobot badan awal dibagi selang waktu penimbangan yaitu 7 hari sekali. Perbandingan rataan pertambahan bobot badan sapi Bali antara yang diberikan pakan silase batang pisang dan yang diberikan batang pisang segar selama penelitian dapat dilihat pada gambar 2
Berdasarkan gambar 2, terlihat bahwa pertambahan bobot badan sapi Bali yang diberikan silase batang pisang lebih tinggi dibandingkan sapi Bali yang diberikan pakan batang pisang segar. Pertambahan bobot badan harian pada sapi yang diberikan silase pada minggu pertama sebesar 42 gram/ekor/hari dan pada minggu 2 hingga minggu ke 4 mencapai 57 gram/ekor/hari sedangkan pada sapi yang diberikan batang pisang segar hanya bertambah sebesar 14 gram/ekor/hari. Perbedaan yang siginifikan ini terjadi karena silase batang pisang memiliki nutrisi yang lebih lengkap jika dibandingkan dengan batang pisang segar.

Selain itu, silase batang pisang tersusun dari berbagai jenis bahan pakan, seperti molases dan dedak padi. Hal ini sejalan dengan pendapat Garsetiasih dkk., (2003) yang menyatakan bahwa dedak padi dapat digunakan sebagai pakan konsentrat yang banyak mengandung energi dan disukai ternak. Dedak padi memiliki kandungan nutrisi yaitu BK 86,5 \%, abu 8,7 $\%$, PK 10,8 \%, serat kasar 11,5\%, lemak 5,1 $\%$, BETN 50,4 \%, kalsium 0,2 \% dan phosfor $2,5 \%$. Pemberian dedak padi sebagai pakan 
penguat ternak ruminansia dapat memberikan pertumbuhan yang baik, ternak cepat besar dan gemuk. Kinerja sapi Bali sangat baik terhadap kondisi lingkungan terutama pakan yang diberikan (Laya, N. K., \& Ngadiyono, N. (2005).

Pertambahan bobot badan selama penelitian dapat dilihat pada gambar 2 dengan rataan pertambahan bobot badan pada minggu pertama sebesar 42 gram/ekor/hari (3 kg/eko/minggu) dan sebesar $57 \quad$ gram/ekor/hari (4 $\mathrm{kg}$ /ekor/minggu). Rataan pertambahan bobot badan ini lebih rendah jika dibandingan dengan pernyataan Mastika (2003) bahwa secara genetik laju pertumbuhan sapi Bali lebih lambat dari sapi Madura, namun dengan pemberian pakan berkualitas baik sapi Bali mampu tumbuh dengan pertambahan bobot badan harian $660 \mathrm{~g} /$ hari pada umur pertumbuhan. Ditambahkan pula oleh Soedjana $d k k$., (2012) yang menyatakan bahwa sapi Bali memiliki kekurangan yaitu pertumbuhannya yang relatif lambat. Akan tetapi, sapi Bali memiliki kelebihan adaptif terhadap lingkungan tropis, mampu hidup dengan pakan berkualitas rendah serta daya tahan yang kuat terhadap penyakit. Tomaszewska dkk., (1993) menyatakan laju pertambahan bobot badan sapi dipengaruhi oleh umur, bobot badan awal fase penggemukan berhubungan dengan berat dewasa yaitu apabila pertumbuhan sapi di awal penggemukan baik, maka pertumbuhan sapi hingga puncaknya juga akan baik. Selain itu, pakan yang diberikan juga merupakan faktor yang mempengaruhi pertambahan bobot badan sapi Bali, baik dari segi kualitas maupun kuantitas

\section{KESIMPULAN}

Berdasarkan hasil penelitian menunjukkan bahwa silase batang pisang sepatu (Musa paradisiaca forma typica) lebih disukai dibandingkan dengan pakan batang pisang segar. Silase batang pisang sepatu
(Musa paradisiaca forma typica) dapat meningkatkan bobot badan sapi Bali dibandingkan dengan batang pisang segar, rata-rata pertambahan bobot badan sapi Bali sebesar 42 hingga 57 gram/ekor/hari.

\section{DAFTAR PUSTAKA}

Balai Penelitian dan Pengembangan Pertanian. 2015. Pengawetan Hijauan DenganCara Silase Untuk Pakan Ternak Ruminansia. Online. http://nad.litbang.pertanian.go.id/in d/index.php/info-teknologi/714pengawetan-hijauan-dengan-carasilase-untuk-pakan-ternak-ruminansia diakses pada tanggal 5 Mei 2019 pukul 20:00 Wita.

Church, D.C. and W.G. Pond. 1988. Basic Animal Nutrition on Feeding. Edisi ke 3. John Wiley \& Sons, New York. $13,45,117$.

Despal, I. G. Permana, S. N. Safarina, \& A. J. Tatra.2011. Penggunaan Berbagai Sumber Karbohidrat Terlarut Air untuk Meningkatkan Kualitas Silase Daun Rami. Media Peternakan Vol 34 (1): 69-76.

Hanafiah, KA. 2004. Rancangan Percobaan. Jakarta: PT Raja Grafindo Persada.

Hardjosubroto, W. $1994 . \quad$ Aplikasi Pemuliabiakan Ternak di Lapangan. Jakarta: PT. Gramedia Widiasarana Indonesia.

Haustein, S. 2003. Evaluating silage quality.\{Online\}

http:www.agric.gov.ab.ca.Diakses 5 Mei 2019.

Garsetiasih, R., NM. Heriyanto dan J. Atmaja (2003) Pemanfaatan Dedak padi sebagai pakan Tambahan rusa 
Timor. Buletin Plasmah Nutfa. Vol 9 no2 23-27. Bogor.

Lawrence, T. L. J. 1990. Influence of Palatability on Diet Asimilation in Non Ruminants in Wiseman, J dan P. J. A Cole (Editor).1990. Feedstuff University Press. Canbridge: 115 141.

Laya, N. K., \& Ngadiyono, N. (2005). Kinerja produksi Sapi Peranakan Ongole (PO) dan Sapi Bali di Propinsi Gorontalo (Doctoral dissertation, [Yogyakarta]: Universitas Gadjah Mada

Mastika, I. M. (2003, February). Feeding strategies to improve the production performance and meat quality of Bali cattle (Bos sondaicus). In Aciar Proceedings (pp. 10-13). ACIAR; 1998

Michael,W. D., C. Keala., and J. Rajesh. 2016. Banana Silage: An Alternative Feed for Swine. University of Hawai'i at Mānoa.

Pane, I. 1990. Upaya peningkatan mutu genetik sapi Bali di P3 Bali. Prosiding Seminar Nasional Sapi Bali. Bali, 20-22 September 1990.

Pasue, I. Saleh, E.J dan Bahri S. (2019). Analisis Lignin, Selulosa Dan Hemi Selulosa Jerami Jagung Hasil Di Fermentasi Trichoderma Viride Dengan Masa Inkubasi Yang Berbeda. Jambura Journal of Animal Science, 1(2) 2019.

DOI: https://doi.org/10.35900/jias.v1i2.2607 http://ejurnal.ung.ac.id/index.php/jj as/article/view/2607/1563

Putu, I. G., P. Situmorang, A. Lubis, T.D. Chaniago, E. Triwulaningsih, T. Sugiarti, I.W. Mathius dan B. Sudaryanto. $1998 . \quad$ Pengaruh pemberian pakan konsentrat tambahan selama dua bulan sebelum dan sesudah kelahiran terhadap performan produksi dan reproduksi sapi potong. In Prosiding Seminar Nasional Peternakan dan Veteriner. Bogor (pp. 1-2).

Reksohadiprodjo, S. 1988. Pakan Ternak Gembala. Yogyakarta: BPFE UGM.

Rizkiyah M dan Agustina D.K. 2016 Pemanfatan Fermentasi Batang Pisang sebagai Pakan Alternatif Ternak Kelinci. Madura Ranch 1(1)

Rokhayati, U. A. dan Pateda S. Y, 2016. Pemanfaatan Batang Pisang Sepatu Sebagai Pakan Alternativ pada Sapi Potong. 1999. KKN Pengabdian. Universitas Negeri Gorontalo, Gorontalo.

Siregar S.B. 1996. Konsep Peraturan Makanan ternak tentang Standar makanan sapi Perah. Usaha Angkasa. Bandung.

Soedjana TD, Bahri S, Diwyanto K, Priyanti A, Ilham N, Muharsini S, Tiesnamurti B. 2012. Menakar potensi penyediaan daging sapi dan kerbau di dalam negeri menuju swasembada 2014. Pusat Penelitian Dan Pengembangan Peternakan. Badan Penelitian dan Pengembangan Pertanian, Kementerian Pertanian. Jakarta

Suprayogi, A., \& Mukhtar, M. (2020). Karakteristik Ekosistem Rumen Sapi Yang Diberi Silase Berbasis Jerami Jagung. Jambura Journal of Animal Science, 2(2), 46-53.

http:/ / ejurnal.ung.ac.id/index.php/jj as/article/view/2348/pdf_1

Tomaszewska, M. W., J.M. Mastika, A Djaja Negara, S. Gardiner, dan T. R. 
Wiradarya.1993. Produksi Kambing dan Domba di Indonesia, Sebelas Maret Universitas Press, Surabaya. 